Special issue of the 3rd International Conference on Computational and Experimental Science and Engineering (ICCESEN 2016)

\title{
Effect of Diffusion Annealing on Borides Layers Produced on XC38 Steel
}

\author{
K.Rayane*, O. Allaoui and A. Allaoui \\ Laboratoire de Génie des Procédés, Université de Laghouat, BP 37G 03000, Algeria
}

\begin{abstract}
In this work, we present a study of the effect of diffusion annealing at $700{ }^{\circ} \mathrm{C}$ for $1 \mathrm{~h}$ on the nature and properties of boride layers obtained on XC38 steel through a molten salt consisting of borax $\left(\mathrm{Na}_{2} \mathrm{~B}_{4} \mathrm{O}_{7}\right)$ and boron carbide $\left(\mathrm{B}_{4} \mathrm{C}\right)$. We evaluated the changes brought by the diffusion annealing on the morphology of the boride layer, the thickness of this layer, the distribution of elements in the steel, and the hardness. Comparing the results obtained allowed concluding that the diffusion annealing will completely transform the two-phase layer formed of $\mathrm{FeB}$ and $\mathrm{Fe}_{2} \mathrm{~B}$ borides in a single-phase layer consisting of single boride $\mathrm{Fe}_{2} \mathrm{~B}$. The transformation of the two-phase boride into a single-phase boride is done with an increase in thickness of about $30 \%$ compared to the initial thickness of the sample. The values of Si concentration obtained in the underlying zone after the diffusion annealing treatment are more important than those obtained in the same underlying zone of samples borided directly by immersion in molten salt consisting of borax and silicon carbide $(\mathrm{SiC})$.
\end{abstract}

DOI: 10.12693/APhysPolA.132.521

PACS/topics: boriding, molten salts, annealing diffusion, XC38 steel

\section{Introduction}

Compared to conventional surface treatments such as carburizing, nitriding, or carbonitriding, boriding treatment leads to surface hardness much higher than those obtained by conventional treatments. Indeed, the hardness of borides obtained on steels is generally higher than $1600 \mathrm{HV}$ and it remains at high temperature, while the hardness obtained on case-hardened steel, nitrided or carbonitrided does not exceed $1000 \mathrm{HV}$ in the best conditions [1]. Thus, the boride layers have excellent resistance to abrasive wear [2].

The main advantage of boriding treatment applied to steels is that it allows combining a high surface hardness at a low friction coefficient, which promotes good wear resistance. Similarly, borided layers have a longer lifetime service and good performance under oxidizing and corrosive atmospheres.

Like all thermochemical surface treatments, boriding can be achieved by various methods and techniques:

- in a solid medium consisting of powders or paste $[3,4]$;

- in a liquid medium molten salt with or without electrolysis [5-7],

- or, finally, in a gaseous medium $[8,9]$.

Each technique or method has advantages and disadvantages.

The diffusion annealing is performed on borided steels (in most cases) to obtain a single-boride $\left(\mathrm{Fe}_{2} \mathrm{~B}\right)$ coating and to improve the mechanical properties at the surface

\footnotetext{
*corresponding author; e-mail: rayanek@lagh-univ.dz
}

of steels. Recently, two methods consisting of boriding followed by a diffusion annealing process (DAP) have been proposed to allow the phase transformation from the FeB coating to the Fe2B coating [9, 10]. A number of works for different purposes were also performed on different types of steel [11-13].

In this work, we have achieved an annealing diffusion treatment at $700\left[{ }^{\circ} \mathrm{C}\right]$ for two hours in objective to convert the dual-phase boride layer $\left(\mathrm{FeB}+\mathrm{Fe}_{2} \mathrm{~B}\right)$ on $\mathrm{XC} 38$ steel obtained by boriding in liquid medium consisting of borax $\left(\mathrm{Na}_{2} \mathrm{~B}_{4} \mathrm{O}_{7}\right)$ added to boron carbide $\left(\mathrm{B}_{4} \mathrm{C}\right)$, to a single-phase boride layer consisting of only $\mathrm{Fe}_{2} \mathrm{~B}$ boride. Morphology, thickness and mechanical characteristics of this layer of single phase obtained after annealing diffusion will be compared with those measured on a single phase boride layer formed directly from a boriding treatment in a bath consisting of borax $\left(\mathrm{Na}_{2} \mathrm{~B}_{4} \mathrm{O}_{7}\right)$ and silicon carbide $(\mathrm{SiC})$.

\section{Experimental procedures}

The chemical composition of XC38 steel samples selected for boriding treatment determined by spectrometric analysis is given in Table I.

TABLE I

Chemical composition [wt\%] of the XC38 steel.

\begin{tabular}{c|c|c|c|c|c|c|c|c}
\hline \hline $\mathrm{C}$ & $\mathrm{Mn}$ & $\mathrm{Si}$ & $\mathrm{P}$ & $\mathrm{S}$ & $\mathrm{Cu}$ & $\mathrm{Cr}$ & $\mathrm{Ni}$ & $\mathrm{Fe}$ \\
\hline 0.39 & 0.68 & 0.34 & 0.026 & 0.025 & 0.18 & 0.19 & 0.26 & bal.
\end{tabular}

Before boriding treatment, all samples have undergone a surface preparation with silicon carbide paper up to grade 1000 to facilitate the boron diffusion through the surface.

The boriding treatment was carried out in molten salts consisting of $70 \%$ borax, completed with $30 \%$ of a reducing agent. The reducing agents used in this work are 
boron carbide $\left(\mathrm{B}_{4} \mathrm{C}\right)$ and silicon carbide $(\mathrm{SiC})$. Treatments of $4 \mathrm{~h}$ at $900^{\circ} \mathrm{C}$ were applied in order to have a thick layer. After boriding, all samples are cooled in air. The annealing diffusion treatment is performed at $720^{\circ} \mathrm{C}$ for one hour.

The identification of borided layers was made by X-ray diffraction using the $K_{\alpha 1}$ of cobalt. The samples' chemical microanalysis of elements before and after boriding was determined using electron microprobe. Microhardness of boride layers and the underlying zone were determined with loads of 25 and $50 \mathrm{~g}$, while that of the substrate was done with a load of $1 \mathrm{~kg}$.

\section{Results and discussions}

\subsection{Boriding treatment}

The boriding treatment in molten salts consisting of $70 \%$ borax, completed with $30 \%$ of $\mathrm{B}_{4} \mathrm{C}$ as reducing agent has yielded on XC38 steel surface a dual-phase borided layer of about $180 \mu \mathrm{m}$ thickness. In Fig. 1a, we can easily distinguish the $\mathrm{FeB}$ boride of $\mathrm{Fe}_{2} \mathrm{~B}$ boride by its darker color, and in Fig. 1b we can note the presence representative peaks of both borides $\mathrm{FeB}$ and $\mathrm{Fe}_{2} \mathrm{~B}$ on the diffractogram.

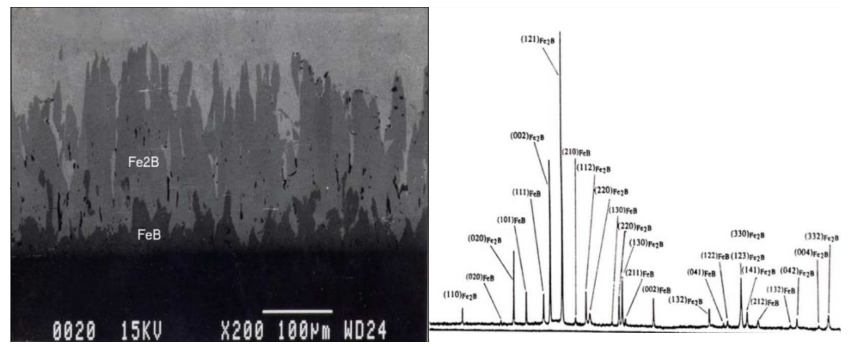

Fig. 1. Microstructure (a) and diffractogram (b) of boride layers on XC38 steel before diffusion annealing treatment with dual phase borides.

\subsection{Diffusion annealing treatment}

The diffusion annealing of previously produced dualphase borided layer should be performed in order to form the single-phase boride layer. Holding at $700{ }^{\circ} \mathrm{C}$ for one hour led to the complete transformation of the dual-phase borided layer consisting of $\mathrm{FeB}$ and $\mathrm{Fe}_{2} \mathrm{~B}$ borides into a single-phase borided layer consisting only of $\mathrm{Fe}_{2} \mathrm{~B}$ boride.

In Fig. $2 \mathrm{a}$ and $\mathrm{b}$, the total absence of $\mathrm{FeB}$ boride (dark zones) in the surface layer formed on XC38 steel can easily be seen after diffusion annealing of one hour at $700^{\circ} \mathrm{C}$. In the diffractogram, in Fig. 2c, one can note the total absence of the representative peaks of the FeB boride.

During annealing diffusion process, carried out in furnace at ambient atmosphere, the transformations take place at the interfaces as follows:

at the interface $\mathrm{FeB} / \mathrm{Fe}_{2} \mathrm{~B}: \quad 2 \mathrm{FeB} \rightarrow \mathrm{Fe}_{2} \mathrm{~B}+\mathrm{B}$; at the interface $\mathrm{Fe}_{2} \mathrm{~B}$ /substrate: $\mathrm{B}+2 \mathrm{Fe} \rightarrow \mathrm{Fe}_{2} \mathrm{~B}$.

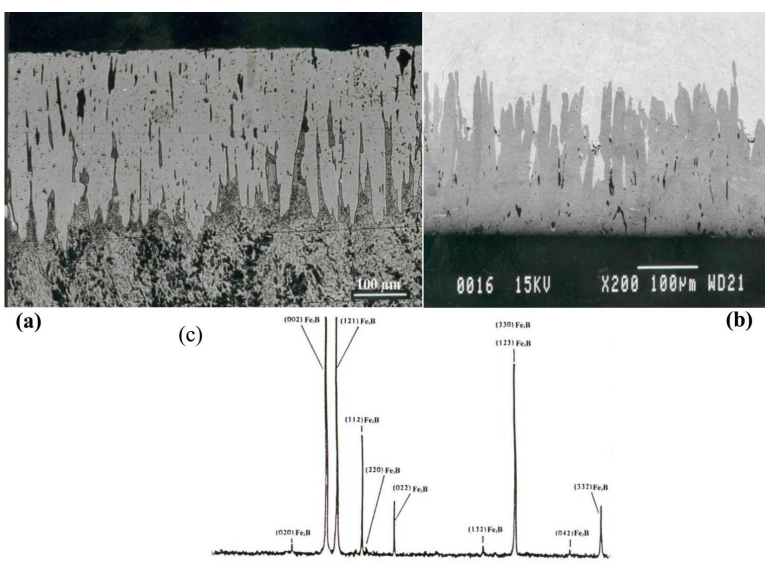

Fig. 2. Microstructures and diffractogram of boride layer on XC38 steel after diffusion annealing treatment.

\subsection{Effect of diffusion annealing on Si distribution in XC38 steel}

In Table II, the distribution of Si in XC38 steel after boriding and diffusion annealing treatment is given.

\section{TABLE II}

Distribution of $\mathrm{Si}$ in XC38 steel directly after boriding in $70 \% \mathrm{Na}_{2} \mathrm{~B}_{4} \mathrm{O}_{7}+30 \% \mathrm{SiC}(\mathrm{A})$, before (B) and after (C) diffusion annealing treatment.

\begin{tabular}{c|c|c|c}
\hline \hline \multirow{2}{*}{} & \multicolumn{3}{|c}{ Silicium [wt\%] } \\
\cline { 2 - 4 } & $\mathrm{A}$ & $\mathrm{B}$ & $\mathrm{C}$ \\
\hline $\mathrm{FeB}$ & - & 0.05 & - \\
$\mathrm{Fe}_{2} \mathrm{~B}$ & 0.03 & 0.02 & 0.01 \\
underlying zone & 0.58 & 0.49 & 0.96 \\
substrate & 0.31 & 0.31 & 0.20
\end{tabular}

According to values of Si distribution in Table II, we can say that the diffusion annealing instead of homogenizing the Si distribution in the different zones has accentuated its concentration in the underlying zone. The presence of high concentration of $\mathrm{Si}$ under the borided layer can be harmful because of the formation of a very soft zone under the very hard borided layer.

\section{Conclusion}

Towards the end of this work, we can advance the following conclusions:

1. The annealing diffusion at $700^{\circ} \mathrm{C}$ for one hour is sufficient to transform completely the dual-phase borided layer in a single-phase borided layer consisting only in the $\mathrm{Fe}_{2} \mathrm{~B}$ boride.

2. The transformation of the dual-phase borided layer in a single-phase borided layer is accompanied by an increase in thickness of about $20 \%$ compared to the initial thickness. 
3. The annealing diffusion caused a significant segregation of silicon in the area underlying the $\mathrm{Fe}_{2} \mathrm{~B}$ boride.

\section{References}

[1] S. Lampman, in: Introduction to Surface Hardening of Steels, Heat Treating, Vol. 4, ASM Handbook, ASM International, 1991, p. 259.

[2] A. Greco, K. Mistry, V. Sista, O. Eryilmaz, A. Erdemir, Wear 271, 1754 (2011).

[3] M. Keddam, S.M. Chentouf, Appl. Surf. Sci. 252, 393 (2005).

[4] M. Keddam, Appl. Surf. Sci. 253, 757 (2006).

[5] O. Allaoui, N. Bouaouadja, G. Saindernan, Surf. Coat. Technol. 201, 3475 (2006).
[6] R. Karim, A. Omar, Def. Diff. Forum 365, 194 (2015).

[7] G. Kartal, O.L. Eryilmaz, G. Krumdick, A. Erdemir, S. Timur, Appl. Surf. Sci. 257, 6928 (2011).

[8] M. Kulka, N. Makuch, M. Popławski, Surf. Coat. Technol. 244, 78 (2014).

[9] M. Kulka, N. Makuch, A. Pertek, L. Małdziński, J. Solid State Chem. 199, 196 (2013).

[10] G. Kartal, S. Timur, V. Sista, O.L. Eryilmaz, A. Erdemir, Surf. Coat. Technol. 206, 2005 (2011).

[11] I. Akkurt, A. Calik, H. Akyıldırım, Nucl. Eng. Des. 241, 55 (2011).

[12] A. Calik, S. Akbunar, N. Ucar, N. Yilmaz, S. Karakas, I. Akkurt, Nucl. Technol. Radiat. Protect. 29, 186 (2014).

[13] I. Akkurt, Ann. Nucl. En. 36, 1702 (2009). 